\title{
Analysis and Treatment Measures of Continuous Emission Monitoring System Fouling in a Coal-Fired Power Plant after Ultra-Low Emission Transformation
}

\author{
ZHENMIN ZHANG, YUJIE ZHU*, JIANJUN SHEN, ANQI TU, YU WU, ZHIYONG ZHANG
}

Inner Mongolia Electric Power Science\&Research Institute, No. 63, South Xilinguole Road, 010020, Hohhot, Inner Mongolia, China

\begin{abstract}
Scanning electron microscopy (SEM) micro-morphology analysis, X-ray diffraction (XRD) and energy-dispersive X-ray diffraction (EDX) component analysis were conducted on the fouling of continuous emission monitoring system (CEMS) sampling tube at the outlet of limestone-gypsum wet flue gas desulfurization (WFGD) of unit 1 in a $600 \mathrm{MW}$ supercritical coal-fired power plant in Inner Mongolia Autonomous Region. The results show that the main component of fouling was ammonium dihydrogen phosphate, which was generated by the reaction between phosphoric acid in the phosphoric acid titration device and the $\mathrm{NH}_{3}$ escaping from the selective catalyst reduction (SCR) denitrification system, and corresponding treatment measures were taken. It indicates that the average value of ammonia escape was reduced from $1.79 \mathrm{ppm}$ to $1.54 \mathrm{ppm}$ through the ammonia injection optimization test of the SCR denitrification system (at the load of $410 \mathrm{MW}$ of the unit), which effectively reduced the generation of fouling. This research provides reference for improving the reliability of coal-fired unit operation after ultra-low emission transformation.
\end{abstract}

Keywords: CEMS fouling, SCR ammonia injection optimization and adjustment, Ultra-low emission transformation, Ammonia escape, Ammonium dihydrogen phosphate

\section{Introduction}

\subsection{Continuous emission monitoring system}

The continuous emission monitoring system (CEMS) is the most important monitoring equipment in the flue gas desulfurization (FGD) system. It is used to monitor the situation of the atmospheric pollutants processed by the FGD system, including particles, gaseous pollutants, and flue gas emission parameters [1]. In China, the CEMS of all coal-fired units is connected to the environmental monitoring network. The environmental protection authorities govern the emissions of atmospheric pollutants from thermal power plants by monitoring the real-time data of CEMS and impose economic penalties and administrative accountability on power plants that cannot stably meet the emission standards $[2,3]$.

One set of wet flue gas desulfurization (WFGD) system is generally equipped with two sets of CEMS. One is installed on the flue of the inlet of the WFGD system, and the other is installed on the inlet of the chimney (Figure 1). General monitoring parameters include $\mathrm{SO}_{2}, \mathrm{NO}_{x}$, particles, $\mathrm{O}_{2}$, flue gas flow, temperature, pressure, and humidity in the WFGD inlet flue and outlet flue [4,5].

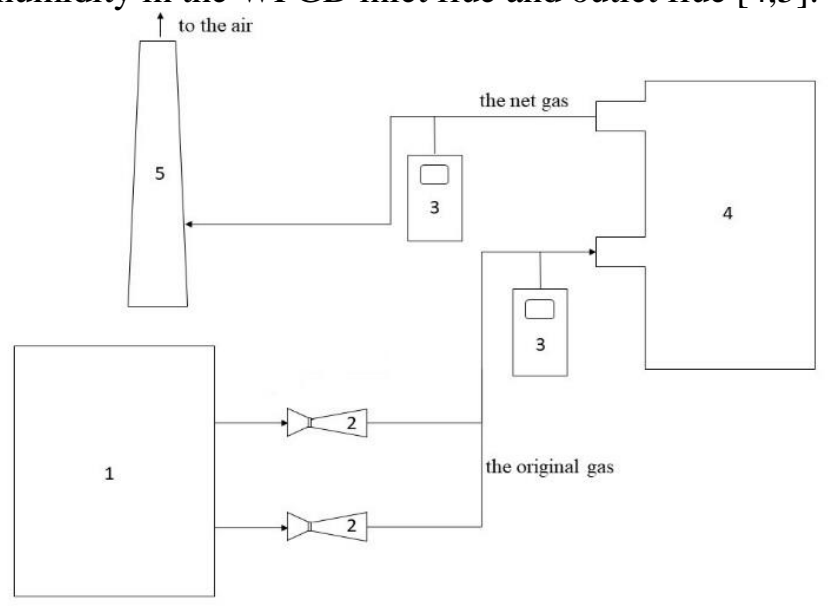

Figure 1. The schematic of CEMS in the WFGD system: 1-main engine of coal-fired power plant; 2-induced draft fan; 3-CEMS; 4-WFGD system; 5-chimney

\footnotetext{
*email: nmdkyzyj@163.com
} 
The CEMS is generally composed of the sampling probe line, sampling condition system (SCS), analysis instrument and data acquisition, transmission, and processing [6] (Figure 2).

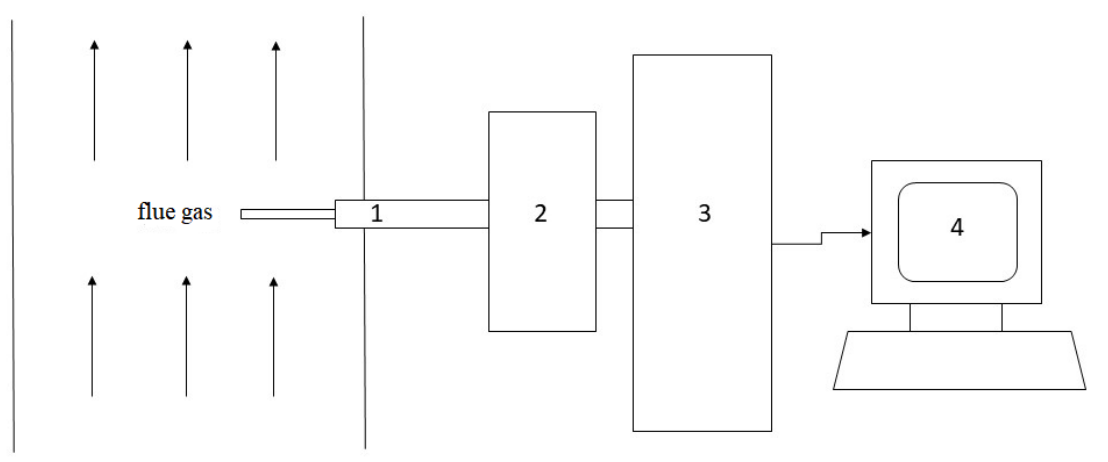

Figure 2. The schematic of CEMS: 1-sampling probe line; 2-SCS; 3-analysis instrument; 4-data acquisition/transmission/processing

$\mathrm{SO}_{2}$ and $\mathrm{NO}_{\mathrm{x}}$ in the flue gas are generally sampled and measured by the direct sampling method [7]. This method is also called the heat tracing pipeline method, which keeps the extracted flue gas (filtered and dedusted) warm by the heat tracing pipeline, so as to keep the flue gas in the non-condensing state and send it to the drying device for dehumidification, and then to the gaseous pollutant concentration analysis unit. The measurement principle of the gaseous pollutant concentration analysis unit is the non-dispersive infra-red (NDIR) method, a measurement method based on the absorption of NDIR radiation. The concentration of the corresponding gas can be measured by measuring the attenuation amplitude of infra-red radiation in the relevant band. Generally speaking, the flue gas sampling flow needs to be greater than $2 \mathrm{~L} / \mathrm{min}$, the flow error is less than $\pm 0.1 \mathrm{~L} / \mathrm{min}$, and the temperature of the heat tracing pipeline is between $140^{\circ} \mathrm{C}$ and $160^{\circ} \mathrm{C}$.

In recent years, as China's in-service coal-fired units' ultra-low emission transformation projects have gradually come to an end, stricter requirements have been imposed on the emission monitoring of atmospheric pollutants after the ultra-low emission transformation. For instance, at a baseline oxygen content of $6 \%$, the mass concentration of $\mathrm{SO}_{2}$ emissions from coal-fired units should not be higher than $35 \mathrm{mg} / \mathrm{m}^{3}$, and the mass concentration of $\mathrm{NO}_{\mathrm{x}}$ emissions should not be higher than $50 \mathrm{mg} / \mathrm{m}^{3}$ [8], imposing higher requirements for the stability and reliability of the overall operation of CEMS. As mentioned above, the performance of CEMS is affected directly by the operating conditions of SCS (Figure 3). The role of SCS is to ensure that the flue gas analyzer obtains a representative sample within the shortest lag time. The status of the sample (temperature, pressure, flow rate, and cleanliness) is suitable for the operating conditions of the analyzer [9]. Taking the detection of $\mathrm{SO}_{2}$ and $\mathrm{NO}_{\mathrm{x}}$ as an example, in SCS, the sample gas is dehumidified and cooled by a highperformance dehumidifier and a heat exchanger (condenser), and the dew point temperature is reduced to about $4^{\circ} \mathrm{C}$ and kept constant. After filtering once again, it enters the NDIR analyzer.

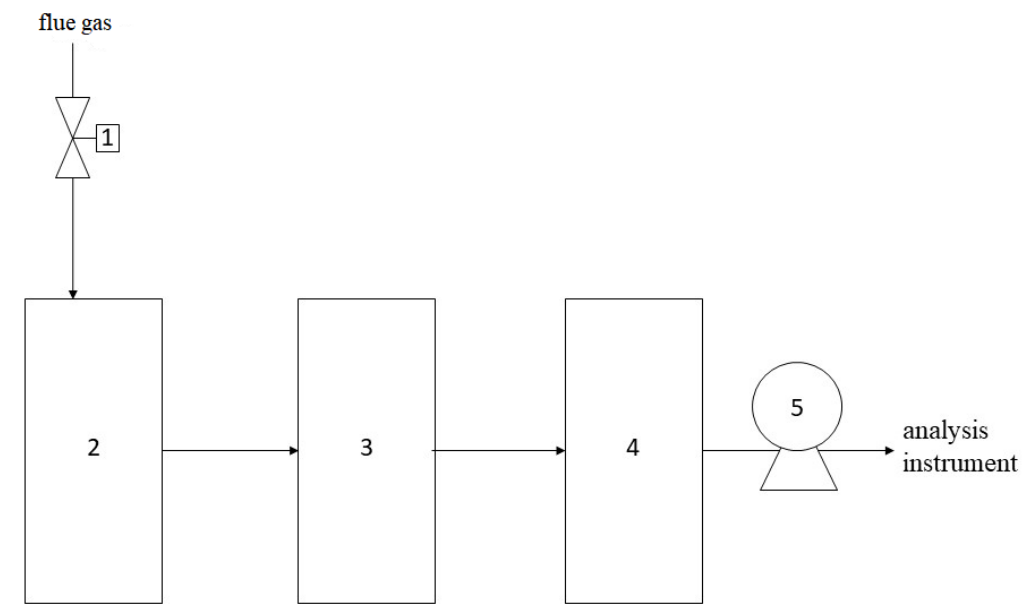

Figure 3. The schematic of SCS (excluding the phosphoric acid titration device): 1-flue gas sampling solenoid valve; 2-condenser; 3-filter; 4-sensors (flow, humidity, etc.); 5 -sampling pump 
In practical applications, the following reactions occur when the sample gas is subjected to the conventional condensation and water removal process in the condenser (see Equation 1):

$$
\mathrm{H}_{2} \mathrm{O}+\mathrm{SO}_{2} \rightarrow \mathrm{H}^{+}+\mathrm{HSO}_{3}^{2-}
$$

As the current coal-fired units mainly adopt SCR [10], or selective non-catalyst reduction (SNCR) [11] denitrification technology (the main reactions are shown in Equation 2 and Equation 3), these two technologies have an ammonia injection process:

$$
\begin{array}{r}
\mathrm{NO}+\mathrm{NH}_{3}+\mathrm{O}_{2} \rightarrow \mathrm{N}_{2}+6 \mathrm{H}_{2} \mathrm{O} \\
\mathrm{NO}+\mathrm{NO}_{2}+\mathrm{NH}_{3} \rightarrow \mathrm{N}_{2}+\mathrm{H}_{2} \mathrm{O}
\end{array}
$$

In order to reach the emission standard of $\mathrm{NO}_{x}$, excessive ammonia injection is generally used during the operation of coal-fired units, which results in the existence of $\mathrm{NH}_{3}$ in the flue gas [12]. For conventional condensing devices, gaseous $\mathrm{SO}_{2}$ will dissolve in liquid water. If $\mathrm{NH}_{3}$ exists in the flue gas, it will become $\mathrm{NH}^{4+}$ and $\mathrm{OH}^{-}$in liquid water, and then reacts with $\mathrm{H}^{+}$to increase the solubility of $\mathrm{SO}_{2}$. Therefore, conventional condensation and water removal result in a large loss of $\mathrm{SO}_{2}$, and the detection value of CEMS is often smaller than the actual value [13].

To prevent from what is mentioned above, some coal-fired units are equipped with a phosphoric acid titration device in the CEMS sampling condition system after the ultra-low emission transformation [14] (Figure 4). The purpose, on the one hand, is to increase the concentration of hydrogen ions in the condenser (Equation 4) and suppress the dissolution of $\mathrm{SO}_{2}$. On the other hand, $\mathrm{H}^{+}$can also react with $\mathrm{OH}^{-}$in solution and absorb $\mathrm{NH}_{3}$.

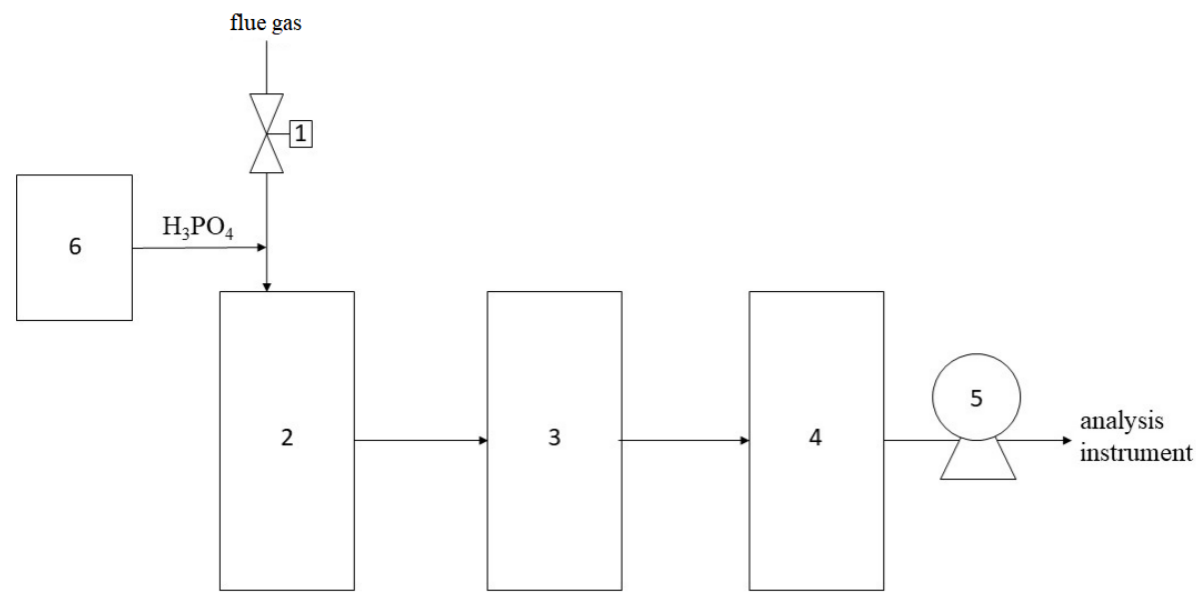

Figure 4. The schematic of SCS, including the phosphoric acid titration device:

1-flue gas sampling solenoid valve; 2-condenser; 3-filter; 4-sensors (flow, humidity, etc.); 5-sampling pump; 6- $\mathrm{H}_{3} \mathrm{PO}_{4}$ titration device.

\subsection{SCR denitrification system}

$$
\mathrm{H}_{3} \mathrm{PO}_{4} \rightarrow \mathrm{H}^{+}+\mathrm{PO}_{4}{ }^{3-}
$$

The principle of the SCR denitrification technology is to use the reduction ability of the reducing agent $\left(\mathrm{NH}_{3}\right)$ on $\mathrm{NO}_{\mathrm{x}}$, to selectively reduce $\mathrm{NO}_{\mathrm{x}}$ in the flue gas into $\mathrm{N}_{2}$ and $\mathrm{H}_{2} \mathrm{O}$ under a certain temperature and catalyst [15]. The basic reaction is shown in Figure 5.

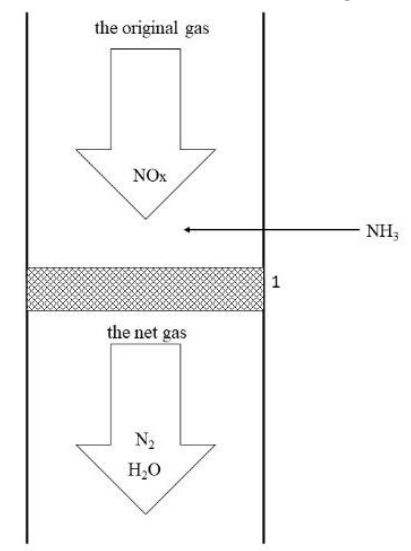

Figure 5. The basic process of the SCR denitrification reaction: 1-catalyst 
In the entire reaction process, in addition to the catalytic reduction of $\mathrm{NH}_{3}$ and $\mathrm{NO}_{\mathrm{x}}$, the chemical reactions involved are as follows:

(1) Main reactions:

$$
\begin{aligned}
& 4 \mathrm{NH}_{3}+4 \mathrm{NO}+\mathrm{O}_{2}=4 \mathrm{~N}_{2}+6 \mathrm{H}_{2} \mathrm{O} \\
& 4 \mathrm{NH}_{3}+2 \mathrm{NO}_{2}+\mathrm{O} 2=3 \mathrm{~N}_{2}+6 \mathrm{H}_{2} \mathrm{O} \\
& 4 \mathrm{NH}_{3}+6 \mathrm{NO}=5 \mathrm{~N}_{2}+6 \mathrm{H}_{2} \mathrm{O} \\
& 8 \mathrm{NH}_{3}+6 \mathrm{NO}_{2}=7 \mathrm{~N}_{2}+12 \mathrm{H}_{2} \mathrm{O}
\end{aligned}
$$

(2) Side reactions:

$$
\begin{aligned}
& 4 \mathrm{NH}_{3}+3 \mathrm{O}_{2}=2 \mathrm{~N}_{2}+6 \mathrm{H}_{2} \mathrm{O} \\
& 2 \mathrm{NH}_{3}=\mathrm{N}_{2}+3 \mathrm{H}_{2} \\
& 4 \mathrm{NH}_{3}+5 \mathrm{O}_{2}=4 \mathrm{NO}+6 \mathrm{H}_{2} \mathrm{O} \\
& 2 \mathrm{NH}_{3}+2 \mathrm{O}_{2}=\mathrm{N}_{2} \mathrm{O}+3 \mathrm{H}_{2} \mathrm{O} \\
& 4 \mathrm{NH}_{3}+4 \mathrm{NO}+3 \mathrm{O}_{2}=4 \mathrm{~N}_{2} \mathrm{O}+6 \mathrm{H}_{2} \mathrm{O}
\end{aligned}
$$

With the progress of the main reactions, side reactions are unavoidable, which accelerate with the increase in temperature. Most experimental studies believe that in the classic SCR reaction, the main reaction is Equation 5 , using the isotopic tracer method to confirm that the nitrogen atoms in $\mathrm{N}_{2}$ in the reaction based on vanadium oxide derives from $\mathrm{NO}$ and $\mathrm{NH}_{3}$, respectively. Equations 10 and 11 in the side reactions are reacted at $350^{\circ} \mathrm{C}$ or higher and are intensified at $450^{\circ} \mathrm{C}$ or higher. The main reaction is presumed to be slow at $450^{\circ} \mathrm{C}$ or lower. With appropriate catalysts, Equations 5 to 8 can be reacted from $200^{\circ} \mathrm{C}$ to $400^{\circ} \mathrm{C}$. Therefore, the catalyst is mainly used to reduce the activation energy of the main reaction so that it can be carried out at a lower temperature and speed up the main reaction rate while inhibiting the progress of side reactions [16,17].

A typical SCR denitrification system is generally composed of an ammonia storage/preparation system, a hybrid system of ammonia gas and air, an ammonia injection system, catalysts, a reactor system, a thermal control system, an auxiliary system, air conditioning and ventilation systems, and so forth. The schematic is shown in Figure 6.

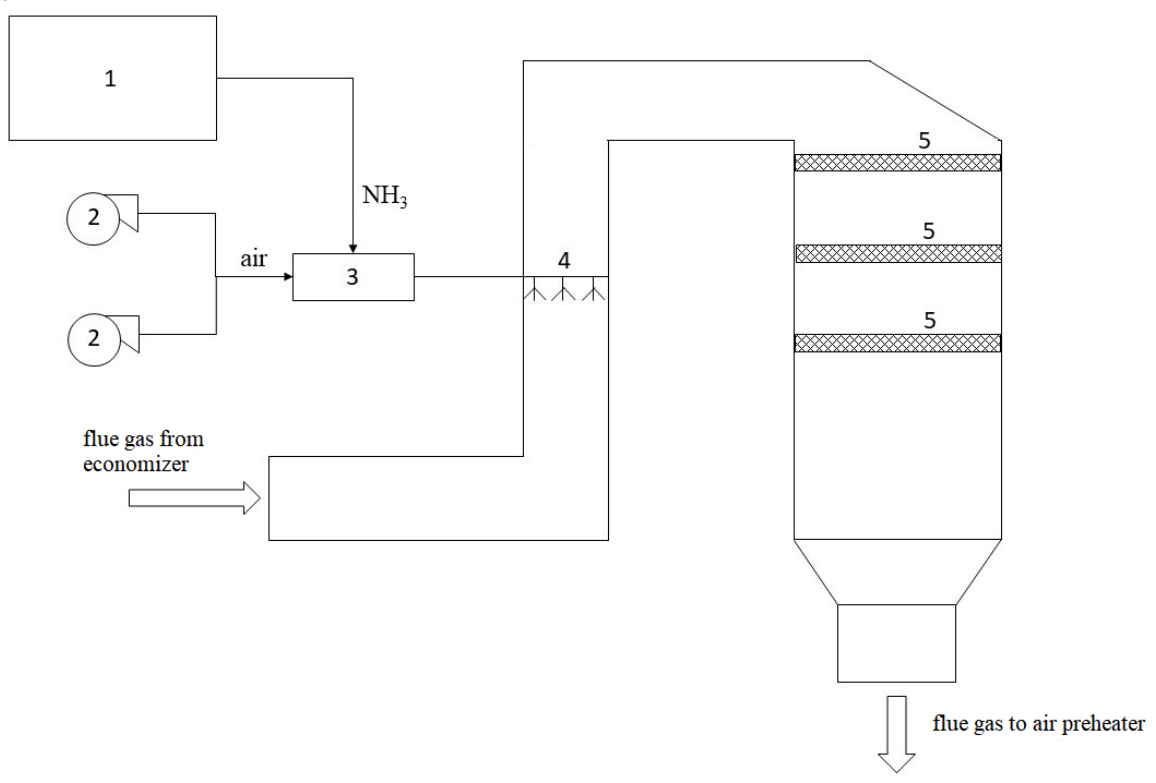

Figure 6. The schematic of the SCR denitrification system: 1-ammonia storage/preparation system; 2-dilution fan; 3-hybrid system of ammonia gas and air; 4-ammonia injection system; 5-catalyst

The high-purity liquid ammonia stored in the liquid ammonia tank is transformed into gaseous ammonia after being heated by the liquefied gas. The gaseous ammonia and the air delivered by the dilution fan are fully mixed in the ammonia gas/air mixer, and the mixed gas is sent to the ammonia injection busbar in front of the catalyst reactor through the ammonia supply pipe, and is finally evenly distributed into the flue in front of the reactor by the ammonia injection grill (AIG). The ammonia gas injected into the flue enters the SCR denitrification reactor vertically from the top to the bottom with the flue gas flow and completes the SCR reaction process with the catalyst at the temperature of $280^{\circ} \mathrm{C}-400^{\circ} \mathrm{C}$, and the $\mathrm{NO}_{\mathrm{x}}$ in the flue gas is catalytically degraded into harmless $\mathrm{N}_{2}$ and $\mathrm{H}_{2} \mathrm{O}[18,19]$. 
The injection amount of ammonia is controlled based on the $\mathrm{NO}_{\mathrm{x}}$ and $\mathrm{O}_{2}$ concentrations at the inlet and outlet of the SCR system, the measured values of the flue gas temperature, the flow of the dilution fan, and the flue gas flow. Generally speaking, during the active period of the catalyst, the technology and control system design of the denitrification system can simultaneously meet the requirements of denitrification efficiency and ammonia escape, but in the actual operation, problems often occur, including the degraded catalyst performance, the unreasonable ammonia injection distribution in the denitrification system, unmatched amount of ammonia injection with the concentration of $\mathrm{NO}_{\mathrm{x}}$, untimely soot blowing and the lagged response of the control system and so forth. Therefore, under the premise of ensuring the $\mathrm{NO}_{\mathrm{x}}$ emission standard and denitrification efficiency, the amount of ammonia escape is often large [20]. Besides, after the ultra-low emission transformation, the ammonia injection amount and the distribution uniformity of the $\mathrm{NO}_{\mathrm{x}}$ concentration at the inlet and outlet of the denitrification system have greatly changed, which is also one of the direct reasons for the excessive ammonia escape.

\subsection{Problems in CEMS of a coal-fired power plant after ultra-low emission transformation}

The flue gas generated by coal-firing in unit 1 (the schematic of the flue gas processing is shown in Figure 7) in a 600 MW supercritical coal-fired power plant in Inner Mongolia Autonomous Region was finally emitted to the chimney after being processed by the denitrification, dedusting, and WFGD system.

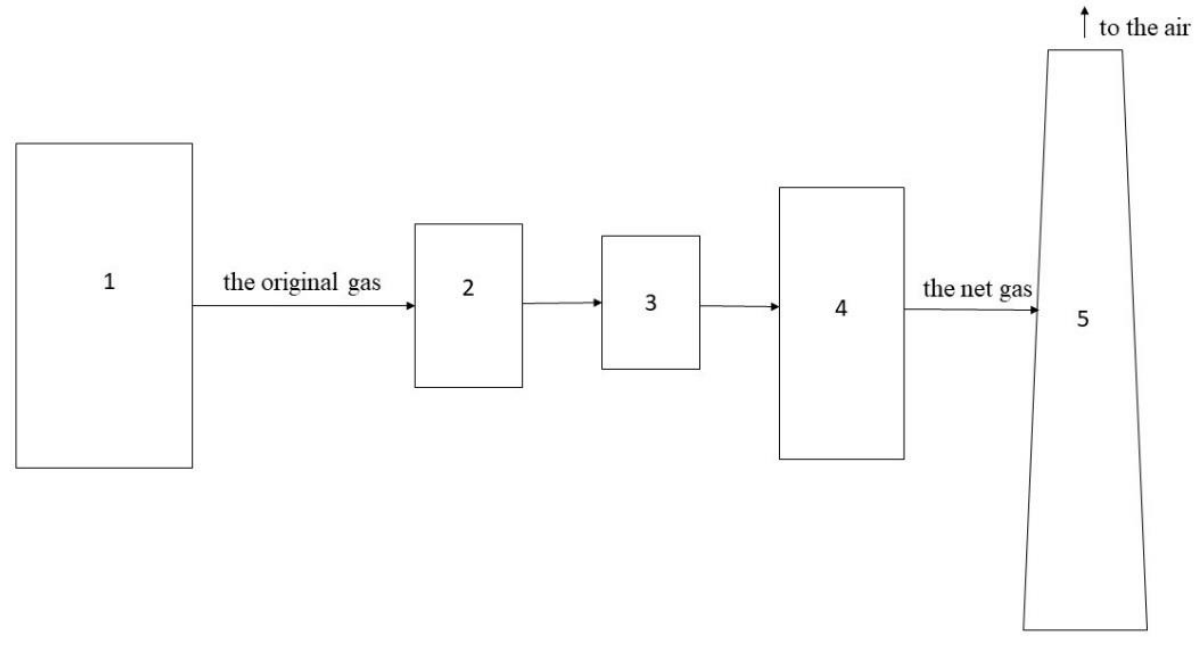

Figure 7. The schematic of the flue gas processing facility: 1-main engine of coal-fired power plant; 2-SCR; 3-electrostatic precipitator; 4-WFGD; 5-chimney

For this unit, two layers of catalyst are laid in the denitrification system before the ultra-low emission transformation and the total resistance of the system is less than $800 \mathrm{~Pa}$ (design value, catalyst resistance + flue resistance). After the ultra-low emission transformation, an additional layer of catalyst is installed and the design resistance is less than $200 \mathrm{~Pa}$. Therefore, the total resistance of the denitrification system after the ultralow emission transformation is less than $1000 \mathrm{~Pa}$. During the catalyst's chemical life cycle, the pressure loss of each layer of catalyst is guaranteed not to increase by more than $20 \%$ in terms of increment.

The type of catalyst is a honeycomb catalyst, and the main components are titanium dioxide $\left(\mathrm{TiO}_{2}\right)$, vanadium pentoxide $\left(\mathrm{V}_{2} \mathrm{O}_{5}\right)$, and tungsten trioxide $\left(\mathrm{WO}_{3}\right)$. The catalyst can operate for a long time when the temperature of flue gas is $<400^{\circ} \mathrm{C}$. Meanwhile, the extreme operating conditions that the catalyst can withstand are when the temperature is $<420^{\circ} \mathrm{C}$, and the continuous running time is not less than five hours.

On each layer of catalyst, four steam soot blowers and eight ultrasonic soot blowers are laid. The soot blower control is incorporated into the design control specification of the denitrification system.

The design parameters of the SCR denitrification inlet are shown in Table 1. 
Table 1. The Design parameters of the SCR denitrification inlet.

\begin{tabular}{|cc|}
\hline Design Parameters & Value \\
\hline Unit load, $\mathrm{MW}$ & 600 \\
$\mathrm{SCR}$ inlet flue gas temperature $(100 \% \mathrm{ECR}),{ }^{\circ} \mathrm{C}$ & 360 \\
$\mathrm{SCR}$ treatment flue gas volume, $\mathrm{m}^{3} \cdot \mathrm{h}^{-1}$ & 1750000 \\
$\mathrm{O}_{2}$ content in inlet flue gas (wet basis, standard state), $\%$ & 3.12 \\
$\mathrm{H}_{2} \mathrm{O}$ content in inlet flue gas (wet basis, standard state), $\%$ & 9.07 \\
$\mathrm{NO}_{\mathrm{x}}$ concentration in inlet flue gas (dry basis, $\left.6 \% \mathrm{O}_{2}\right), \mathrm{mg} \cdot \mathrm{m}^{-3}$ & $\leq 450$ \\
Denitrification efficiency $(100 \% \mathrm{ECR}), \%$ & $\geq 90$ \\
Ammonia escape (dry basis, $\left.6 \% \mathrm{O}_{2}\right), \mathrm{ppm}$ & $\leq 8$ \\
\hline
\end{tabular}

The system adopts the limestone-gypsum WFGD process (no flue gas bypass and the designed desulfurization efficiency > 95\%); one set of the WFGD system is generally equipped with two sets of CEMS, of which the flow rate of the phosphoric acid titration device is $12 \mathrm{~mL} / \mathrm{h}$, and the concentration of phosphoric acid is $0.5 \%$ (mass ratio). Since the completion of the ultra-low emission transformation of the unit on April 1, 2019, the CEMS sampling tubes of SCS (Figure 8) at the WFGD outlet were frequently clogged, and the unit had to conduct multiple load limit operations to eliminate blockage failures, making the unit's operation highly unreliable.

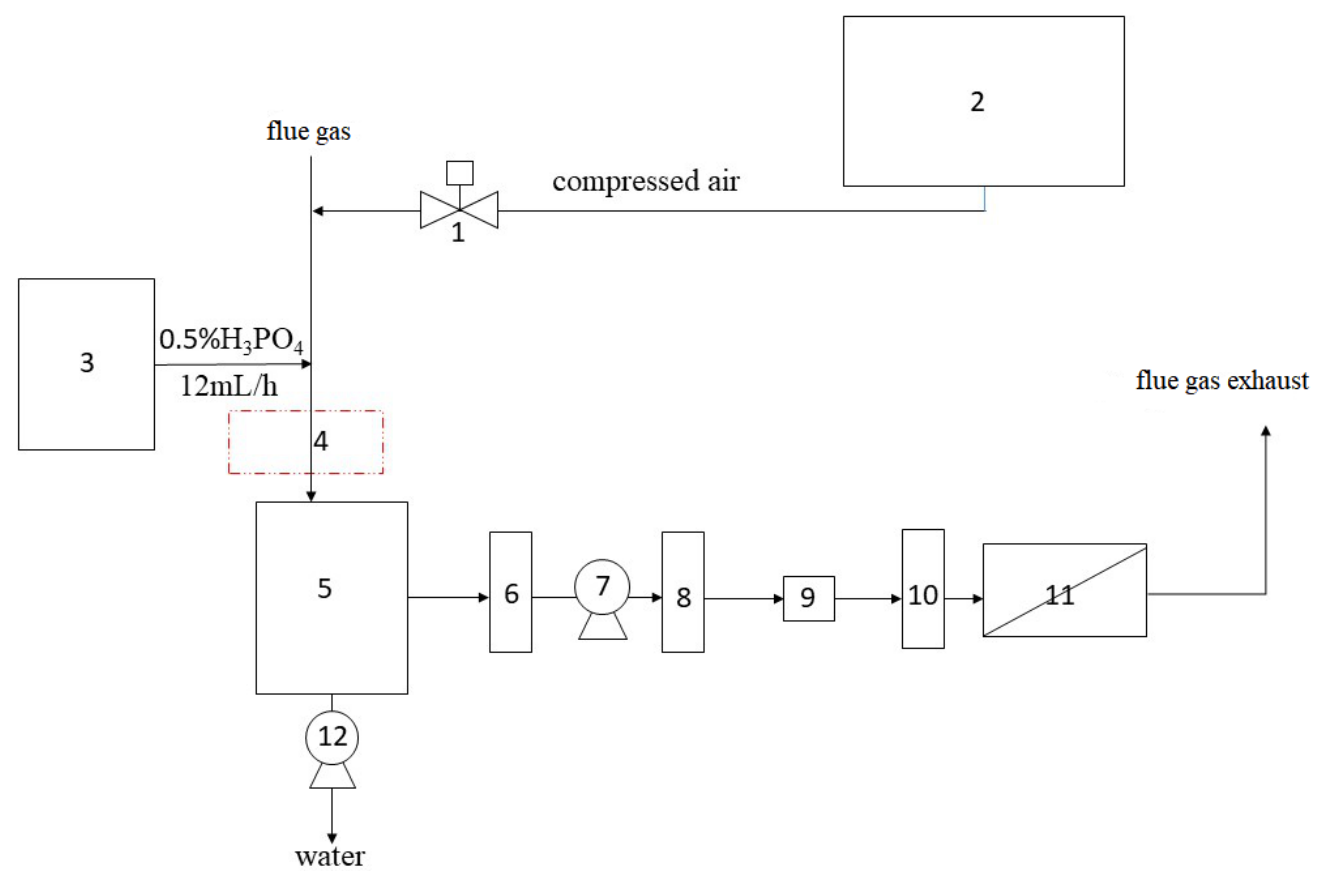

Figure 8. The schematic of fouling location: 1-flue gas sampling solenoid valve;

2-backflushing system; $3-\mathrm{H}_{3} \mathrm{PO}_{4}$ titration device; 4-fouled sampling tube (heat tracing temperature, $140{ }^{\circ} \mathrm{C}$ ); 5-condenser; 6-filter I; 7-sampling pump; 8- filter II; 9-humidity alarm; 10-precision filter; 11- $\mathrm{SO}_{2}$ analyzer

To determine the composition of the clogged material, the analysis and adjustment tests were conducted as shown in Section 2.

\section{Materials and methods}

\subsection{Fouling sample analysis test}

After the CEMS sampling tube was dissembled, we found that the clogged material was off-white fouling (Figure 9). To determine its composition, scanning electron microscopy (SEM) (Hitachi SU3900) micromorphological analysis, X-ray diffraction (XRD) (Rigaku D/max2500), and energy-dispersive X-ray diffraction (EDX) (SHIMADZU 8100) composition testing were conducted: 


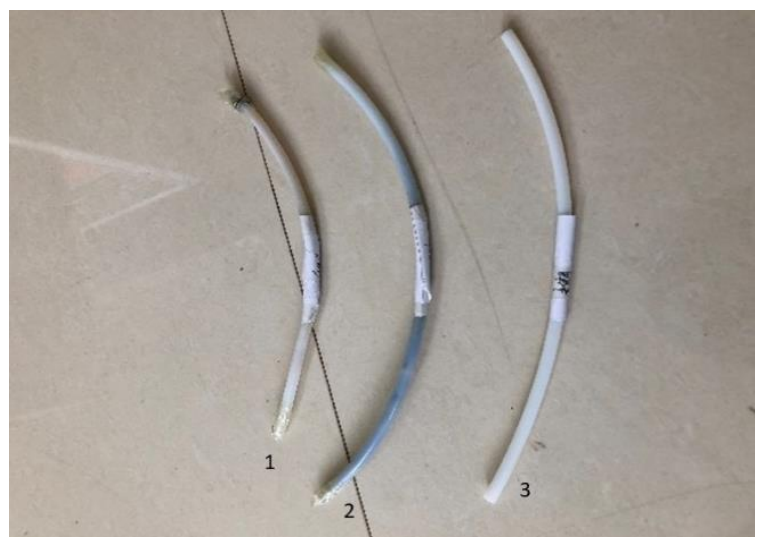

Figure 9. Fouled sampling tubes: 1-a completely clogged tube after running for one month; 2 -a tube with fouling after running for ten days; 3 -unused tube

\subsection{Ammonia injection optimization and adjustment test of the SCR denitrification system}

\subsubsection{Positions of measuring points and testing instrument and equipment}

The optimization and adjustment test was carried out at 410 MW (major adjustment of load condition, condition 1), $320 \mathrm{MW}$ (verifying condition, condition 2) and $550 \mathrm{MW}$ (verifying condition, condition 3). The test was performed with the grid method. The positions of the measuring points are shown in Figure 10, where the flue gas inlet measuring point is arranged on the flue before AIG, and the flue gas outlet measuring point is arranged on the reactor outlet flue. The testing instrument and equipment are shown in Table 2.

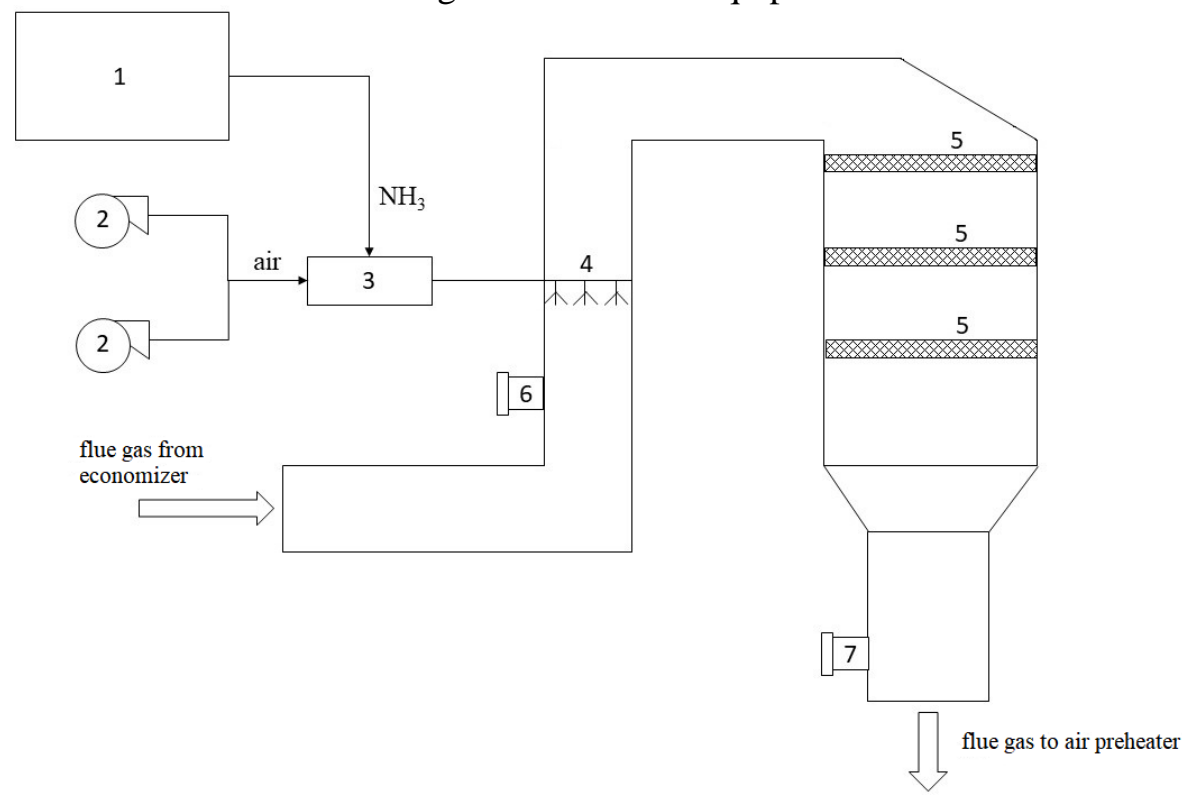

Figure 10. Positions of the measuring points of the ammonia injection optimization and adjustment test of the SCR denitrification system: 1-liquid ammonia storage and evaporation system;

2-dilution fan; 3-hybrid system of ammonia gas and air; 4-ammonia injection system; 5-catalyst; 6-SCR inlet measuring point; 7-SCR outlet measuring point

Table 2. Instrument and Equipment of the Ammonia injection optimization and adjustment test

\begin{tabular}{|ll|}
\hline Instrument and Equipment & Model \\
\hline Automatic smoke/gas tester & LaoYing-3012H \\
Flue gas analyzer & Gasmet-DX4000 \\
Flue gas analyzer & Testo-350 \\
Flue gas pre-processor & Kane-9008JCT-SL \\
\hline
\end{tabular}




\subsubsection{Test procedure}

The test was performed in the following three steps:

Step 1: First, under condition 1, the denitrification efficiency was kept at $\geq 75 \%$, the flow field parameters of the upstream of AIG was tested with the grid method, and the $\mathrm{NO}_{\mathrm{x}}$ concentration distribution and the outlet ammonia escape concentration at the inlet and outlet sections of the reactor were tested.

Step 2: Based on the result in step 1, under condition 1, according to the $\mathrm{NO}_{\mathrm{x}}$ concentration and ammonia escape concentration at the outlet of the reactor, the opening of each AIG branch pipe were manually adjusted repeatedly one by one for redistribution of each branch's flow according to course adjustment based on the width direction of the reactor and then the fine adjustment based on the depth of the reactor.

Step 3: After the adjustment in step 2, the $\mathrm{NO}_{\mathrm{x}}$ concentration distribution test at the reactor outlet was respectively performed under the load of conditions 2 and 3 when its relative standard deviation was less than $20 \%$, so as to verify the uniformity of the $\mathrm{NO}_{\mathrm{x}}$ concentration distribution at the outlet. Then, the fine adjustment was performed on the opening of each AIG branch pipe according to the measurement results for the optimization and adjustment under different loads.

\section{Results and discussions}

\subsection{Fouling sample analysis}

\subsubsection{X-ray diffraction (XRD)}

The XRD map is shown in Figure 11. The results show that the fouling component is ammonium dihydrogen phosphate $\left(\mathrm{NH}_{4} \mathrm{H}_{2} \mathrm{PO}_{4}\right)$.

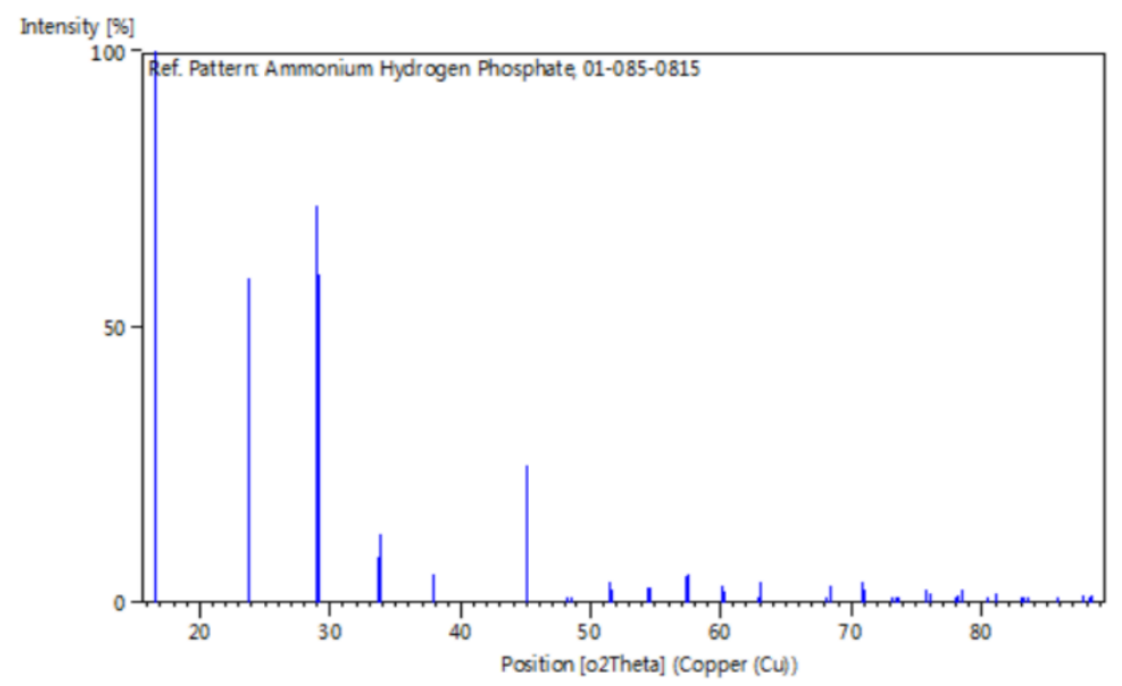

Figure 11. The XRD map of the fouling

\subsubsection{Scanning electron microscopy (SEM)}

By scanning electron microscopy (SEM) at a magnification of 2000 times, the crystal structure of fouling can be observed. As shown in Figure 12, within the field of view, the fouling mainly manifests as irregular smooth plaques under the SEM.

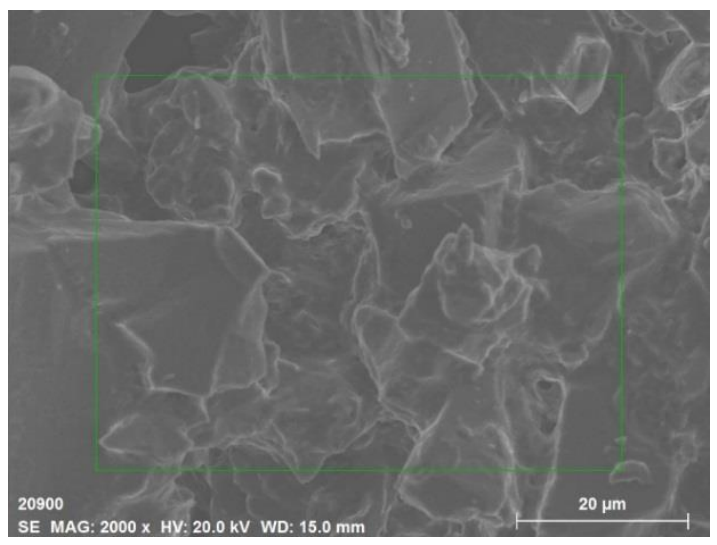

Figure 12. The SEM image of the fouling 


\subsubsection{Energy-dispersive X-ray diffraction (EDX)}

The EDX element scan results are shown in Figure 13. The oxygen element (green spot) and phosphorus element (blue spot) take up the largest proportion in the scanning area, which basically agrees with the phosphate shown in the XRD test.

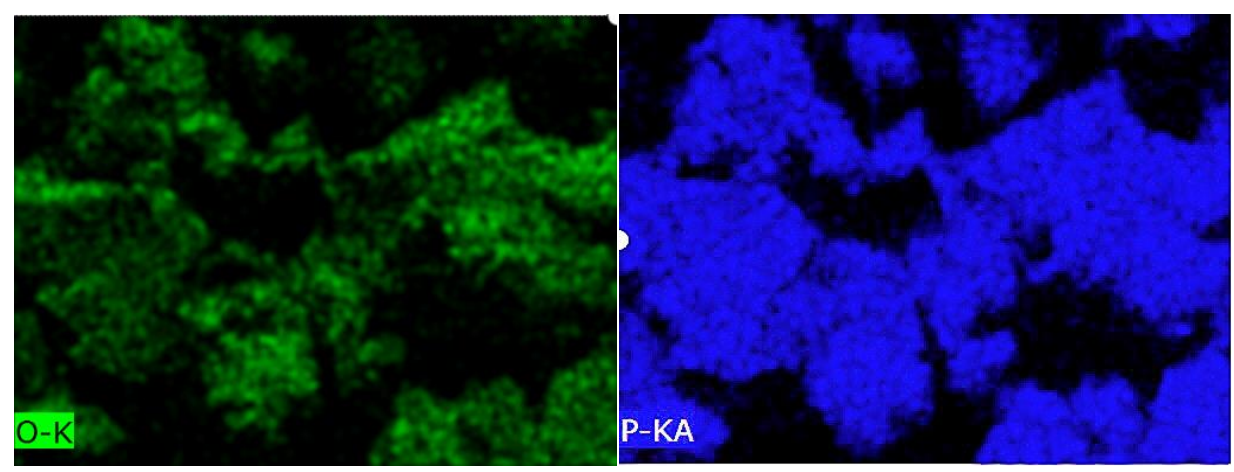

A
B

Figure 13. The element distribution of the fouling: A. oxygen element (green spot); . phosphorus element (blue spot)

After XRD and SEM analysis, an energy spectrum scan of the typical crystal structure of the fouling was conducted to determine its elemental composition and atomic ratio again. It is found after EDX (Figure 14) and calculation (Table 3) that such type of crystal is mainly composed of $\mathrm{O}, \mathrm{P}, \mathrm{C}, \mathrm{N}$, and $\mathrm{S}$, and their atomic ratios are $53.44 \%, 18.34 \%, 16.08 \%, 11.16 \%$, and $0.98 \%$, respectively. The atomic ratio of $\mathrm{O}, \mathrm{P}$, and $\mathrm{N}$ in the fouling sample is about $3: 1: 1$, which is basically consistent with the XRD test results.

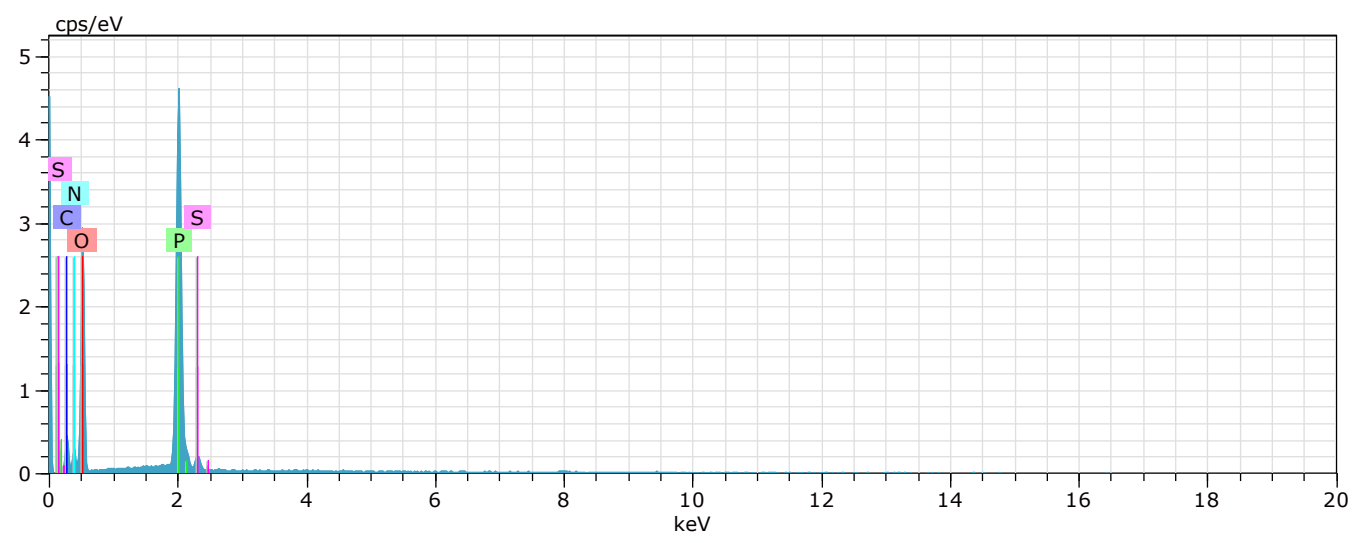

Figure 14. EDX of the fouling

Table 3. Atomic ratios of main elements in the white fouling sample in crystal forms

\begin{tabular}{|c|c|c|c|c|c|c|}
\hline Element & $\mathrm{O}$ & $\mathrm{P}$ & $\mathrm{C}$ & $\mathrm{N}$ & $\mathrm{S}$ & Total \\
\hline $\begin{array}{c}\text { Norm.c } \\
\text { (wt.\%) }\end{array}$ & 53.44 & 18.34 & 16.08 & 11.16 & 0.98 & 100.00 \\
\hline
\end{tabular}

Based on the above analysis and tests, it can be determined that the leading cause for CEMS's blockage is the formation of ammonium dihydrogen phosphate in the sampling pipeline. It is generated by the reaction of phosphoric acid and excessive $\mathrm{NH}_{3}$ in the denitrification system in the sampling pipeline (Eq. 14).

$$
\mathrm{H}_{3} \mathrm{PO}_{4}+\mathrm{NH}_{3} \rightarrow \mathrm{NH}_{4} \mathrm{H}_{2} \mathrm{PO}_{4}
$$

One possible reason for this phenomenon is that the escaped $\mathrm{NH}_{3}$ in the denitrification system was not completely absorbed by the condensation system after entering the sample condition system, and the semi-liquid ammonium dihydrogen phosphate was formed when the $\mathrm{NH}_{3}$ and phosphate were at about $140^{\circ} \mathrm{C}$. The ammonium dihydrogen phosphate has high viscosity and constantly adheres to a small amount of particulates in 
the sampling gas in the system operation, leading to gradually increasing solid volume, and eventually causing the complete blockage of the sampling tube.

Based on the above analysis and conclusions, the engineering staff decided to start solving the problem by reducing the amount of ammonia escape.

\subsection{Ammonia injection optimization and adjustment of the SCR denitrification system}

The optimization and adjustment tests aim to adjust the ammonia gas flow of each branch of the AIG system, eliminate local excessive ammonia escape peak values, improve the distribution deviation of the molar ratio of ammonia to nitrogen at the inlet of the reactor, increase the uniformity of the $\mathrm{NO}_{\mathrm{x}}$ concentration distribution at the outlet of the SCR denitrification system, and reduce the amount of ammonia escape from the outlet of the reactor, thereby fundamentally reducing the amount of ammonia escape into the desulfurated CEMS system as well as the possibility of fouling generation [21,22].

The main test indexes after the optimization and adjustment tests are shown in Table 4.

Table 4. Test results of ammonia escape in unit 1

\begin{tabular}{|c|c|c|c|c|c|c|c|c|}
\hline \multirow[t]{2}{*}{ Test items } & \multicolumn{2}{|c|}{$\begin{array}{l}\text { Condition } 1 \text { before } \\
\text { optimization and } \\
\text { adjustment test }\end{array}$} & \multicolumn{2}{|c|}{$\begin{array}{l}\text { Condition } 1 \text { after } \\
\text { optimization and } \\
\text { adjustment test }\end{array}$} & \multicolumn{2}{|c|}{ Condition 2} & \multicolumn{2}{|c|}{ Condition 3} \\
\hline & A side & B side & A side & B side & A side & B side & A side & B side \\
\hline $\begin{array}{l}\text { SCR denitrification } \\
\text { efficiency, \% }\end{array}$ & 90.33 & 89.05 & 92.34 & 90.17 & 85.45 & 86.98 & 91.25 & 92.76 \\
\hline $\begin{array}{c}\text { Ammonia escape } \\
\text { value, } \mathrm{ppm}\end{array}$ & 1.70 & 1.88 & 1.52 & 1.56 & 2.13 & 1.84 & 1.51 & 1.22 \\
\hline $\begin{array}{c}\text { Ammonia escape } \\
\text { value in the SCR } \\
\text { denitrification } \\
\text { system, ppm }\end{array}$ & \multicolumn{2}{|c|}{1.79} & \multicolumn{2}{|c|}{1.54} & \multicolumn{2}{|c|}{1.98} & \multicolumn{2}{|c|}{1.36} \\
\hline
\end{tabular}

Note: To ensure the uniformity of the reaction, the SCR reactor is divided into two sides (A and B), and the flue

gas enters the reactor from both sides. After the reaction is completed, the flue gas flows into the outlet flue at the reactor outlet.

It can be seen from Table 4 that under the load of condition 1 before the optimization and adjustment, the average values of ammonia escape concentration at the outlets of A side and B side were $1.70 \mathrm{ppm}$ and 1.88 $\mathrm{ppm}$, respectively, and the average value of ammonia escape in the SCR denitrification system was $1.79 \mathrm{ppm}$. After optimization and adjustment, the average values of ammonia escape concentration at the outlets of A side and B side were $1.52 \mathrm{ppm}$ and $1.56 \mathrm{ppm}$, respectively, and the average value of ammonia escape in the SCR denitrification system was $1.54 \mathrm{ppm}$. The average value of ammonia escape concentration in the denitrification system decreased by $14.00 \%$. In condition 2 , the average values of ammonia escape concentration at the outlets of A side and B side were $2.13 \mathrm{ppm}$ and $1.84 \mathrm{ppm}$, respectively, and the average value of ammonia escape in the SCR denitrification system was $1.98 \mathrm{ppm}$; in condition 3, the average values of ammonia escape concentration at the outlets of A side and B side were $1.51 \mathrm{ppm}$ and $1.22 \mathrm{ppm}$, respectively, and the average value of ammonia escape in the SCR denitrification system was $1.36 \mathrm{ppm}$.

It can be observed from the optimization and adjustment test that after the optimization and adjustment, the denitrification efficiency, ammonia escape concentration all meet the design value requirements of the unit, and the ammonia escape concentration significantly dropped.

\section{Conclusions}

As of the end of the third quarter of 2018, China's coal-fired units realizing ultra-low emission reached 750 million $\mathrm{kW}$, accounting for more than $75 \%$ of all coal-fired units. China has built the world's largest clean coal power supply system [23]. The achievements made by China's coal-fired power plants in terms of controlling three major pollutants: soot, $\mathrm{SO}_{2}$ and $\mathrm{NO}_{\mathrm{x}}$, have won widespread acclaim, contributing tremendously to improving China's atmospheric environment quality [24]. However, we must also take into account that as China's coal-fired units gradually enter the "post-era" of ultra-low emission transformation, problems have also become gradually prominent in the operation of some flue gas treatment facilities. Among them, as an important facility for testing the flue gas treatment facilities on the atmospheric pollutant treatment level, CEMS is critical in the operation of coal-fired power plants. Once a problem occurs, both the economic benefits of coal-fired power plants and the surrounding environment would be directly affected and threatened. Therefore, equipment maintenance personnel must always pay attention to the running status of CEMS, especially when there are 
problems such as clogged sampling tubes and abnormal data transmission, etc., they need to find the cause in time and eliminate the fault. However, after the ultra-low emission transformation, the excessive use of denitrifying reducing agent has brought a series of problems and hidden dangers to the SCR's subsequent flue gas treatment facilities (including CEMS). Many problems have never occurred before the ultra-low emission transformation, and the problem addressed in this paper is one of them. In this paper, SEM micro-morphological analysis, XRD, and EDX composition analysis of the clogged materials in the CEMS sampling tube were performed. The results indicate that the clogging of the CEMS sampling tube was mainly caused by the solid ammonium dihydrogen phosphate produced by ammonia and phosphoric acid. Excessive $\mathrm{NH}_{3}$ in the SCR denitrification process is the leading cause of this problem. After the ammonia injection optimization and adjustment test in the SCR denitrification system, the amount of ammonia escape was reduced. To date (December 2019), CEMS has been operating stably for more than two months, and the clogging was significantly reduced, indicating that the adjustment method is practical and effective. Similar conditions may still occur after the ultra-low emission transformation of coal-fired units is completed. Therefore, the analysis and resolution of the fault can offer valuable reference for the operation and maintenance of similar type of units.

Acknowledgments: This study was funded by the Inner Mongolia Electric Power Science\&Research Institute (Inner Mongolia Autonomous Region, China) 2019 Research Fund Project (No: 2019-zc-11).

\section{References}

1. LI, M.M., PANG, B., GUO, X., Selection and application of CEMS in ultra-low emission reformation of coal-fired plant, Electric Power Technology and Environmental Protection, 33(6), 2017, 53-54, in Chinese.

2. HAN, C., MA, X.X., SHEN, W.C., DONG, S.B., WANG, X.N., CAO, X., XU, J.F., Application Research of Intelligent Security System in Thermal Power Plants, Electric Power, 52(3), 2019, 127, in Chinese.

3. ZHANG, J., ZHENG, C.H., ZHANG, Y.X., Experimental investigation of ultra-low pollutants emission characteristics from a $1000 \mathrm{MW}$ coal-fired power plant, Proceedings of the CSEE, 36(5), 2016, 1310-1314, in Chinese.

4. YANG, R.M., Selection of CEMS measuring instruments in power plants after ultra-low emission transformation, Industrial Instrumentation and Automation, 6, 2018, 17, in Chinese.

5. LI, J., SHI, R.Q., XU, C.L., WANG, S.M., Process identification of the SCR system of coal-fired power plant for de-NO $\mathrm{N}_{\mathrm{x}}$ based on historical operation data, Environ. Technol., 40(25), 2019, 3287.

6. SHUAI, W., LI, L., CUI, Z.M., WU, J.Y., MO, H., Analysis of primary air pollutant emission characteristics and reduction efficiency for ultra-low emission coal-fired power plants based on actual measurement, Electric Power, 48(1), 2015, 131-137, in Chinese.

7. TANG, L.H., Some attentive problems in installation and shakedown of direct extraction CEMS, Electric Power Environmental Protection, 21(1), 2005, 58, in Chinese.

8. ZHOU, S.X., YU, F.P., LI, Q.Y., HU, D.Q., The Monitoring for Gaseous Pollutants at Low Concentrations in Coal-fired Power Plants, Journal of Engineering for Thermal Energy and Power, 32(4), 2017, 130, in Chinese.

9. MENG, S.H., HUAN, P.Y., HU, D.Y., Improvement and Maintenance of Gas Pretreatment Unit of CEMS, Electric Power Science and Engineering, 27(4), 2011, 58.

10. TANG, S.J., LU, Q., WANG, Z.X., WU, Y.T., DONG, C.Q., YANG, Y.P., Life prediction of SCR flue gas denitration catalyst in coal-fired power plants, Thermal Power Generation, 48(3), 2019, 61, in Chinese.

11. ZHAO, K., KANG, L.S., GUAN, H.Y., LI, S.Y., A Review of Selective Non-catalytic Reduction (SNCR) Denitrification in Circulating Fluidized Bed, Energy Conservation Technology, 35(6), 2017, 514, in Chinese.

12. YU, B., LI, J., XU, X.Q., CHEN, X.B., Research on Clogging Control Technology for Air Preheater of Coal-fired Power Plant under New Emission Standards, Zhejiang Electric Power, 37(1), 2018, 62, in Chinese.

13. GAO, W., XU, W.L., Analysis on Sample Gas Dewatering Technology and Application in Flue Gas CEMS, China Environmental Protection Industry, 5, 2018, 41, in Chinese.

14. ZHAO, J.B., ZHU, W., ZHANG, Q.X., Research and Application of Condensation Pretreatment System Based on Phosphoric Acid Titration in CEMS System, China Environmental Protection Industry, 10, 2018, 40, in Chinese.

15. ANSTROM, M., TOPøE, N.Y., DUMESIC, J.A., Density functional theory studies of mechanistic aspects of the SCR reaction on vanadium oxide catalysts, J. Catal., 213(2), 2003, 115.

16. MA, S.C., JIN, X., SUN, Y.X., CUI, J.W., The Formation Mechanism of Ammonium Bisulfate in SCR Flu Gas Denitrification Process and Control Thereof, Thermal Power Generation, 39(8), 2010, 12, in Chinese. 
17. ABUELNUOR, A.A.A., WAHID, M.A., MOHAMMED, H.A., SAAT, A., Flameless combustion role in the mitigation of $\mathrm{NO}_{\mathrm{x}}$ emission: a review, International Journal of Energy Research, 38(7), 2014, 827.

18. GAO, Y.H., LIU, Q.C., BIAN, L.T., Numerical Simulation and Optimization of Flow Field in the SCR Denitrification System on a 600 MW Capacity Units, Energy Procedia, 14, 2012, 370.

19. NISHAD, K., SADIKI, A., JANICKA, J., Numerical Investigation of Adblue Evaporation and Thermal Decomposition in the Context of $\mathrm{NO}_{\mathrm{x}}$-SCR Using a Multi-component Evaporation Model, Energies, 11(1), 2018, 222.

20. YOU, S.L., LUO, H.H., WANG, Z., YAO, Y.Q., LIU, X.R., SUN, Y.Q., CHEN, F., Study on Ammonia Escape Rate Control Technology of SCR Denitrification System in Coal-fired Power Plant, Huandian Techonlogy, 41(2), 2019, 55, in Chinese.

21. LIU, J.L., LIU, Y.H., ZHI, D., LI, Q., Experimental analysis of optimized adjustment of ammonia injection in SCR flue gas denitrification system of exhaust-heat boiler of $300 \mathrm{MW}$ unit, Electric Power Technology and Environmental Protection, 35(5), 2019, 23, in Chinese.

22. WANG, Z.W., LIU, T.A., LI, X., YU, L.X., Test and Analysis of Uniforming Ammonia Distribution of SCR Flue Gas Denitrification System in Given Power Plant, Northeast Electric Power Technology, 38(3), 2017, 24.

23. ZHU, F.H., LI J.Z., Questions and Suggestions on the Control of $\mathrm{SO}_{3}$ and Condensable Particulate Matter from Coal-fired Power Plants in China, Environmental Impact Assessment, 41(3), 2019, 5,1.

24. LI, J.G., ZHU, F.H., SUN, X.L., Current status and challenges of atmospheric pollution prevention and control of thermal power plants in China, Electric Power, 51(6), 2018, 2, in Chinese.

$\overline{\text { Manuscript received: 27.02.2020 }}$ 